\title{
'Marketmore 97': A Monoecious Slicing Cucumber Inbred with Multiple Disease and Insect Resistances
}

\author{
Jason Cavatorta ${ }^{1}$, George Moriarty, Mark Henning, Michael Glos, \\ Mary Kreitinger, and Henry M. Munger \\ Department of Plant Breeding, Cornell University, 320 Bradfield Hall, \\ Ithaca, NY 14853
}

\author{
Molly Jahn \\ Department of Plant Breeding, Cornell University, Ithaca, NY 14853; and \\ College of Agricultural and Life Sciences, University of Wisconsin, Madison, \\ WI 53706
}

Additional index words. cucumber, Cucumis sativus, powdery mildew, Sphaerotheca fuliginea, vegetable breeding

\begin{abstract}
Marketmore 97' is the most recent addition to a series of disease-resistant slicing cucumbers developed in the Cornell University Department of Plant Breeding. The fruit have green skin with white spines and an average length and diameter of 18.8 $\mathrm{cm}$ and $4.8 \mathrm{~cm}$, respectively. Broad resistance to a number of destructive diseases and insects makes this cultivar well-suited to low-input agricultural systems at the scale of the home gardener or the commercial grower. In addition to the cucumber mosaic virus (CMV), cucumber scab (Cladosporium cucumerinum Ell. \& Arth.), downy mildew (Pseudoperonospora cubensis Berk \& Curtis), and powdery mildew (Sphaerotheca fuliginea Schl. ex Fr.) resistances of 'Marketmore 76', 'Marketmore 97' contains resistance to alternaria leaf spot [Alternaria alternata (Fr.) Keis.], Ulocladium leaf spot (Ulocladium cucurbitae Let. \& Roum.), target leaf spot (Corynespora cassiicola Berk. \& Curt.), watermelon mosaic virus, papaya ringspot virus, and zucchini yellow mosaic virus. Furthermore, the bitterfree character of this cultivar is responsible for nonpreference of the striped cucumber beetle (Acalymma vittatum Fab.) and spotted cucumber beetle (Diabrotica undecimpunctata howardi Barber). Finally, a near isogenic line of 'Marketmore 97' is available that is gynoecious. A replicated trial of 'Marketmore 97' conducted in New York in 2006 confirmed comparable yield and quality to other Marketmore cultivars.
\end{abstract}

\begin{abstract}
'Marketmore 76' has been widely planted since it was first introduced 30 years ago and represents one of the most successful cucumber cultivars ever released. Despite the subsequent development of numerous higheryielding hybrids (Rowell et al., 2002), the
\end{abstract}

\footnotetext{
Received for publication 29 Nov. 2006. Accepted for publication $23 \mathrm{Jan} .2007$.

We acknowledge the contribution of the following individuals for technical support during the development of this cultivar: Brynda Beeman, Maryann Fink, Matt Falise, Gregory Inzinna, and Nicholas Strutt. We also thank Todd Wehner for his critical review of this manuscript.

The 'Marketmore 97' photograph was graciously supplied by Territorial Seed Company. Financial support was provided by the Vegetable Breeding Institute and by USDA grants IFAFS No. 200152100-11347, OREI No. 2004-51300-02229, and SARE No. LNE04-204.

${ }^{1}$ To whom reprint requests should be addressed; e-mailJRC87@cornell.edu
}

elevated levels of disease resistances combined with improved color and quality have long made this open-pollinated cultivar a standard slicing cucumber. Decades of cucumber breeding efforts at Cornell have continued to focus on resistance breeding and have generated a series of cucumbers combining disease resistances and other traits, including 'Marketmore', 'Marketmore 70', 'Marketmore 76', 'Marketmore 87', and 'Marketmore 88 '. This article highlights the most recent development, 'Marketmore 97', and presents data regarding the relative performance of 'Marketmore 97' and 'Marketmore 76 ', the most widely grown comparable cultivar.

Resistance breeding in cucumber first began in the United States to address the problem of cucumber mosaic virus (CMV), the most destructive disease of cucumber at that time. Initial crosses to the cultivar 'White Spine' were conducted at Cornell University by Oved Shifriss and C.H. Myers using the oriental cultivar Chinese
Long, which had been introduced to the United States by R.H. Porter of Iowa State University (Porter, 1929). The largely recessive character of this CMV resistance (Shifriss et al., 1942) was lost during multiple backcross generations. Consequently, early generations relied heavily on the pedigree method (Munger, 1993) (Fig. 1). Crosses were made to several commercially acceptable varieties, selffed for numerous generations and, to maintain CMV resistance, crossed to an advanced line between 'Chinese Long' and several other popular varieties. Scab resistance was introgressed to develop 'Marketmore', which quickly gained popularity. A major flaw of this cultivar is that it tends to form light-colored fruit when grown at high temperatures. Introgression of the $u$ gene (Strong, 1930) for uniform fruit color was achieved by backcrossing to the sister line 'Tablegreen', resulting in 'Marketmore 70'.

The prolonged longevity of foliage in the field resulting from CMV and scab resistance resulted in the prominent appearance of mid- to late-season powdery mildew infection. To address this issue, powdery mildew resistance (PMR) from C.E. Peterson's cultivar 'Spartan Salad' was added to 'Marketmore 70 ' by backcrossing five times alternating with two generations of self-pollination (Jahn et al., 2002). The resulting cultivar was named 'Marketmore 76 ' and proved to be more widely adapted than earlier versions of 'Marketmore'. Around this time, it was noticed that the PMR trait of 'Marketmore 76' was in an unfavorable linkage with resistance to target leaf spot (Corynespora cassiicola) (Lane and Munger, 1985). Increased resistance to this and several other foliar pathogens was obtained by crossing with 'Wisconsin 2757' and backcrossing to 'Marketmore 76' to produce 'Marketmore 87'. Finally, 'Marketmore 97' was developed by adding resistance to zucchini yellow mosaic virus (ZYMV), watermelon mosaic virus (WMV), and papaya ringspot virus (PRSV) from 'Marketmore 88' (Fig. 1).

\section{Description and Performance}

The fruit of 'Marketmore 76' and 'Marketmore 97' are nearly identical in length, diameter, weight, and appearance (Table 1). Both are thick-skinned slicing cucumbers that ship well and are not easily bruised or scarred. They have cylindrical-shaped fruit with small white spines and dark green skin with faint light green striping when mature (Fig. 2). All cultivars in the 'Marketmore' series have average-sized vines with dark green leaves that, as a result of resistance to a number of foliar pathogens, tend to remain on the plant well into the growing season.

'Marketmore 76 ' is resistant to CMV, cucumber scab (Cladosporium cucumerinum), 


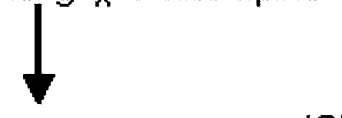

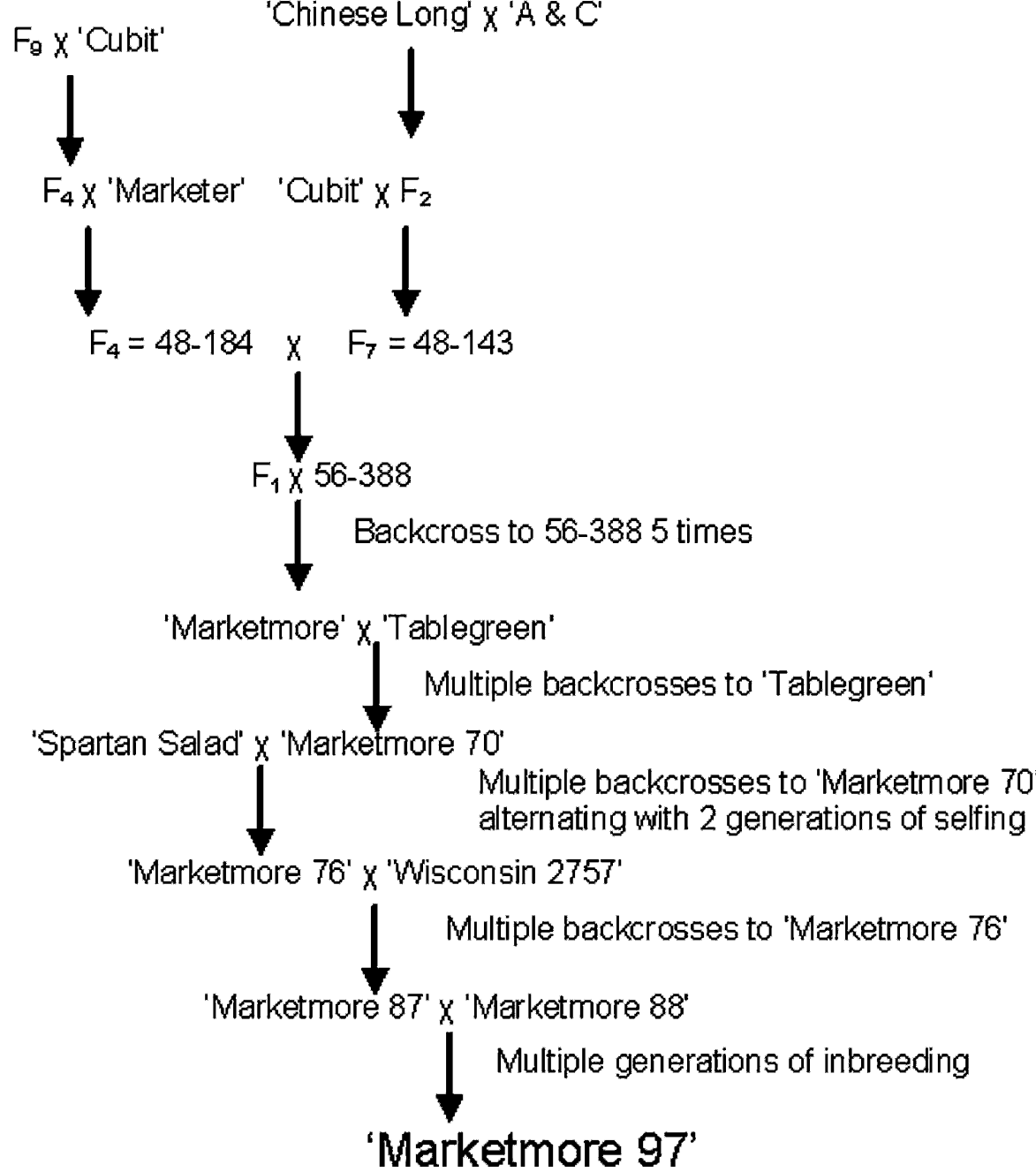

Fig. 1. Pedigree of several members of the 'Marketmore' series, including 'Marketmore 97'. Modified from Munger (1993).

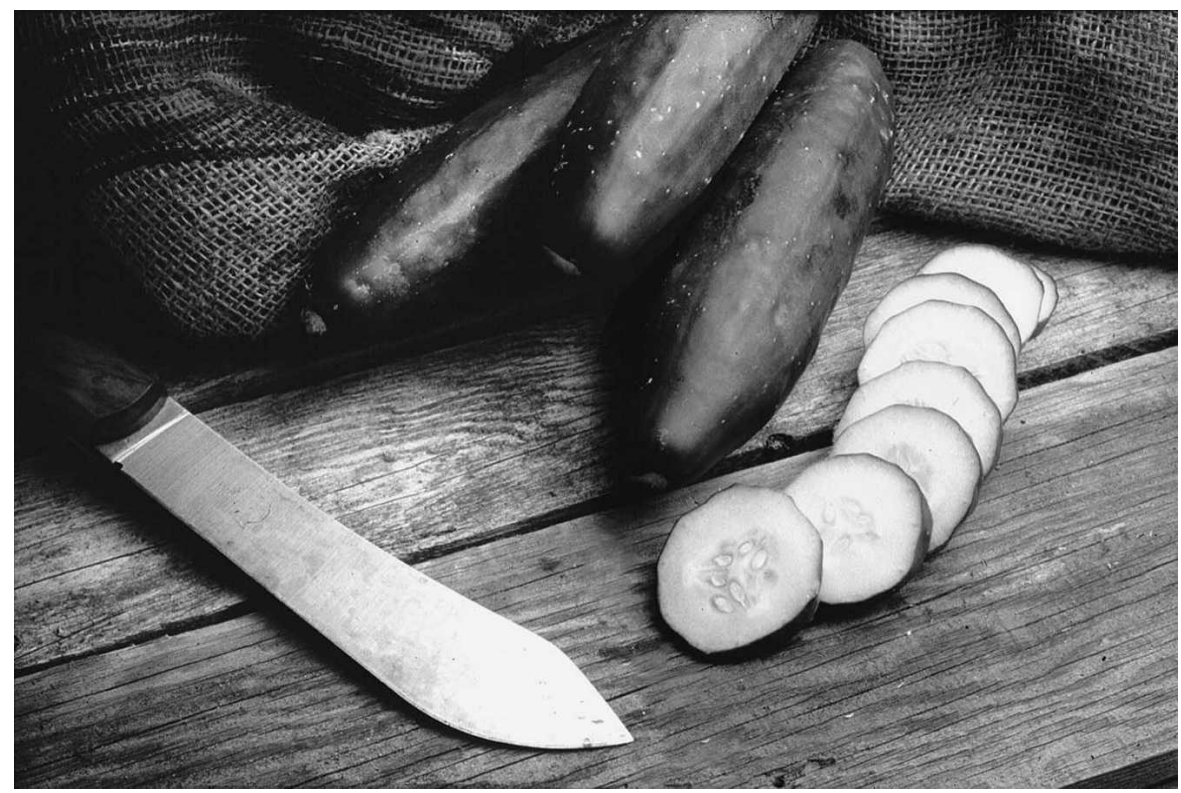

Fig. 2. 'Marketmore 97' fruit at a harvestable stage. Used with permission of the Territorial Seed Company. downy mildew (Pseudoperonospora cubensis), and powdery mildew (Sphaerotheca fuliginea). The development of 'Marketmore 97' resulted from the addition of resistance to the following diseases: alternaria leaf spot (Alternaria alternata), ulocladium leaf spot (Ulocladium cucurbitae), target leaf spot (Corynespora cassiicola), WMV, PRSV, and ZYMV. 'Marketmore 76' contains high levels of cucurbitacins that provide resistance to spider mites (Tetranychus urticae). In contrast, 'Marketmore 97' contains low levels of cucurbitacins that make it susceptible to spider mites but a poor host for cucumber beetles (Acalymma vittatum Fab. and Diabrotica undecimpunctata howardi Barber). 'Marketmore $97 \mathrm{~F}$ ' is a gynoecious nearisogenic line of 'Marketmore 97' that has identical fruit characteristics but slightly higher yields (unpublished data).

Most resistant germplasm sources contain numerous undesirable horticultural traits. The biggest challenge during the development of 'Marketmore 97' has been the uncoupling of resistance traits from reduced yield, poor fruit quality, and delayed flowering. Through decades of intensive selection, significant progress has been achieved. Although 'Marketmore 97' ultimately yields as high as or higher than 'Marketmore 76' (Table 1), it is several days later (Fig. 3). Selection for earlier flowering continues but appears to be correlated with a considerable yield penalty (unpublished data).

In conclusion, resistance breeding in cucumber began with the objective of developing resistance to a single disease. However, once this work was completed, additional diseases began to appear that previously had not been problematic. This process has continued for 70 years and has culminated in cucumber germplasm resistant to many diseases. In this article, we present 'Marketmore 97', the newest disease- and insect-resistant slicing cucumber released from Cornell University. It has fruit qualities similar to earlier 'Marketmore' cultivars but has combined resistances to 10 diseases and to cucumber beetles, is bitterfree, and is available as the gynoecious near-isogenic line 'Marketmore 97F'. We expect this cultivar to perform particularly well in lowinput agricultural settings and as a resistance source for further breeding and hybrid development. 
Table 1. Comparisons between 'Marketmore 97', Cornell's latest disease-resistant slicing cucumber, and 'Marketmore 76'.

\begin{tabular}{lcccccc}
\hline Cultivar & $\begin{array}{c}\text { Fruit length } \\
(\mathrm{cm})\end{array}$ & $\begin{array}{c}\text { Fruit diam. } \\
(\mathrm{cm})\end{array}$ & $\begin{array}{c}\text { Fruit wt. } \\
(\mathrm{g})\end{array}$ & $\begin{array}{c}\text { Days to } \\
\text { harvest }^{\mathrm{y}}\end{array}$ & $\begin{array}{c}\text { Avg. fruit } \\
\text { per plant }^{\mathrm{x}}\end{array}$ & $\begin{array}{c}\text { Avg. yield } \\
\text { per plant }(\mathrm{g})^{\mathrm{x}}\end{array}$ \\
\hline 'Marketmore 76' & $18.3 \pm 2.1$ & $4.8 \pm 0.6$ & $237 \pm 66$ & 52 & 13.7 & 3655 \\
'Marketmore 97' & $18.8 \pm 2.0$ & $4.8 \pm 0.6$ & $247 \pm 66$ & 54 & 14.6 & 3688 \\
\hline
\end{tabular}

zParameters considered include fruit length, diameter, and weight as well as earliness and yield. Fruit size measurements are reported with the standard deviation of the sample.

${ }^{y}$ Days to harvest refers to number of days from transplanting into the field until first marketable fruit. 'Sample sizes for 'Marketmore 76' and 'Marketmore 97' were 297 and 289 fruit and 19 and 17 plants, respectively, divided among three replicates. Harvestable fruit was collected three times a week for 5 weeks.

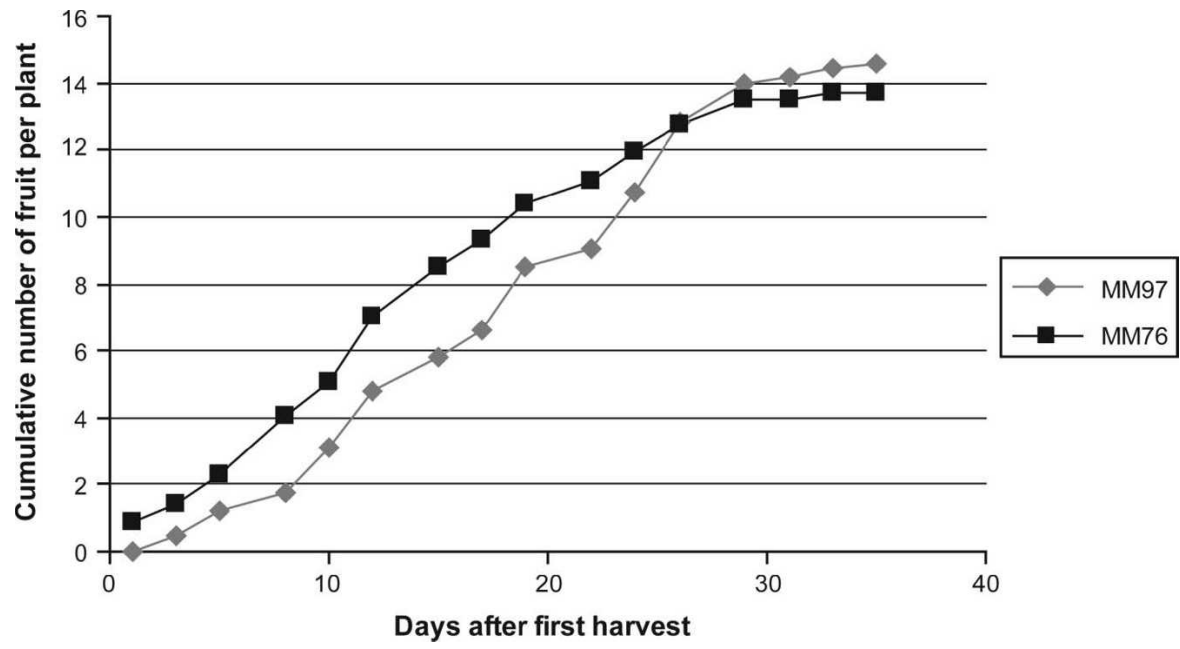

Fig. 3. Cumulative number of fruit per plant plotted against number of days after first harvest. 'Marketmore 97 ' yields at least as much as 'Marketmore 76 ' but is several days later.

\section{Availability}

'Marketmore 97 ' is a released cultivar and is available from several seed companies, including Abundant Life Seeds, Territorial Seed Company, and Turtle Tree Seeds. 'Marketmore $97 \mathrm{~F}$ ' is available from the authors on request.

\section{Literature Cited}

Jahn, M., H. Munger, and J. McCreight. 2002. Breeding cucurbit crops for powdery mildew resistance, p. 239-248. In: R. Belanger, W. Bushnell, A. Dik, and T. Carver (eds.). The powdery mildews: A comprehensive treatise. Amer. Phytopathol. Soc., St. Paul, Minn.

Lane, D. and H. Munger. 1985. Linkage between Corynespora leafspot resistance and powdery mildew susceptibility in cucumber. HortScience 20:593 (abstr.)

Munger, H.M. 1993. Breeding for viral disease resistance in cucurbits, p. 44-60. In: M. Kyle (ed.). Resistance to viral diseases of vegetables. Timber Press, Portland, Ore.

Porter, R.H. 1929. Reaction of Chinese cucumbers to mosaic. Phytopathology 19:85 (abstr.).

Rowell, B., A. Satanek, D. Slone, and J. Snyder. 2002. Yields and gross returns from new slicing cucumber varieties, p. 32-35. In: 2002 Fruit and vegetable crops report. University of Kentucky College of Agr., Lexington.

Shifriss, O., C.H. Myers, and C. Chupp. 1942. On resistance to the mosaic virus in cucumber. Phytopathology 32:773-784.

Strong, W.J. 1930. Breeding experiments with the cucumber (Cucumis sativus L.). Sci. Agr 11:333-346. 